\title{
Different Cytotoxic Effects of Vetiver Oil on Three Types of Cancer Cells, Mainly Targeting CNR2 on TNBC
}

\author{
Mila Hanifa ${ }^{1}$, Raditya Wulandari ${ }^{1}$, Ummi Maryam Zulfin ${ }^{1}$, Eri Prasetyo \\ Nugroho $^{1}$, Sari Haryanti ${ }^{2}$, Edy Meiyanto ${ }^{1,3 *}$
}

\begin{abstract}
Objective: To investigate vetiver oil (VO) selectivity effects on several cancer cell types and identify the $\beta$-caryophyllene role and mechanisms to prevent cancer development. Methods: Cytotoxic effects of VO on three types of cancer cells (WiDr, 4T1, T47D) were determined using MTT assay. VO's effects on the cell cycle and apoptosis were analyzed using flow cytometry. Intracellular Reactive Oxygen Species (ROS) of cells after treatment with VO was observed with DCFDA staining. Bioinformatics study and molecular docking were used to determine the molecular targets of VO. Results: VO contained various essential oils in which $\beta$-caryophyllene was the most abundant. 4T1 cells performed the lowest $\mathrm{IC}_{50}$ value. WiDr and 4T1 cells showed an arrest in the G2/M phase, while T47D showed an increase of sub G1 population after VO treatment. On the other hand, apoptosis was only observed in WiDr and T47D cells. ROS levels were increased significantly in WiDr and T47D cells but not in 4T1 cells. Cannabinoids CB2 receptor (CNR2) was highly expressed in 4T1 cells and commonly exhibited a low survival rate on Triple Negative Breast Cancer (TNBC) patients. CNR2 was the notable target of $\beta$-caryophyllene and performed agonistic interaction, which might have contributed to its cytotoxic activity against 4T1 cells. Conclusion: The molecular interaction of VO cannabinoid agonists and the CNR2 receptor was the underlying cause of VO cytotoxicity, which is a VO distinction on TNBC. Therefore, VO is better suited for use as an anti-cancer agent in TNBC cells.
\end{abstract}

Keywords: Vetiver oil- $\beta$-caryophyllene- cytotoxic- TNBC- CNR2

Asian Pac J Cancer Prev, 23 (1), 241-251

\section{Introduction}

Cannabinoids receptor (CNR) has been studied as a potential target for treating various diseases, including the progression of cancer and its deteriorating prognosis (Kisková et al., 2019). There are two types of CNR (CNR1 and CNR2), which belong to the seven trans-membranes superfamily receptors (Raup-Konsavage et al., 2018). CNR1 is highly expressed in brain areas, and it is found to be low in the peripheral nervous system, testes, prostate, uterus, and vascular endothelium. Therefore, this receptor is dominant in cognitive function, memory, anxiety, pain, motor regulation, and endocrine regulation (Dhopeshwarkar and Mackie, 2014). Meanwhile, high expression of CNR2 is found in the immune system cells, but it is also functionally expressed in the brain (Feng et al., 2015; Elbaz et al., 2017). The different tissue distributions of CNR1 and CNR2 allow different receptor effects with selective and specific activation pathways. Both types of CNR are highly expressed in various cancer tissues, but CNR2 plays a more critical role in carcinogenesis and cancer development (Raup-Konsavage et al., 2018).

CNR2 regulates diverse signaling pathways involving Gi/o-dependent inhibition of adenylyl cyclase, stimulation of mitogen-activated protein kinase (MAPK), phosphoinositide 3-kinase (PI3K), and cyclooxygenase-2 (COX-2) signaling, and activation of de novo ceramide synthesis (Raup-Konsavage et al., 2018). Several studies have found that when cancer cells are treated with cannabinoid agonists, the PI3K/Akt and MAPK/ ERK signaling pathways are involved in controlling cell proliferation and survival (Khan et al., 2018). The inhibition of Akt leads to cell cycle arrest, which has been directly linked to cannabinoid agonists by controlling cell cycle checkpoints (Park et al., 2011). In leukemic cells, ceramide induces apoptosis by regulating the p38 MAPK signaling, while in lung cancer, the ceramide-dependent pro-apoptotic effect appears to be mediated by the up-regulation of COX-2 expression and the increased synthesis of the pro-apoptotic prostaglandin E-2 (PGE-2), which are triggered by cannabinoid agonists (Hinz and Ramer, 2019).

${ }^{1}$ Cancer Chemoprevention Research Center, Faculty of Pharmacy, Universitas Gadjah Mada, Sekip Utara II, 55281 Yogyakarta, Indonesia. ${ }^{2}$ Herbal and Traditional Medicine Research Center, Ministry of Health, Republic of Indonesia. ${ }^{3}$ Faculty of Pharmacy, Universitas Gadjah Mada, Sekip Utara II, 55281 Yogyakarta, Indonesia. *For Correspondence: edy_meiyanto@ugm.ac.id 
Cannabinoid compounds, both non-specific and non-selective agonists for CNR1 or CNR2, have been shown to modulate the tumor microenvironment through induction of apoptosis in different models of tumor cells (Hanlon et al., 2016). Interestingly, CNR2-selective cannabinoid ligands are able to treat malignancy of CNR2 expression without causing any psychotropic effects (Feng et al., 2015). $\beta$-caryophyllene belongs to the phytocannabinoids, which can activate the cannabinoid receptors (CNR1 and CNR2); however, $\beta$-caryophyllene has a solid affinity to CNR2, and it has no affinity to CNR1 (Fidyt et al., 2016). $\beta$-caryophyllene is one of the major active essential oils easily found in spices and plants, including in vetivers (Chrysopogon zizanioides L.) (Chahal et al., 2015). Vetiver cultivated from South India showed $0.37 \%$ of $\beta$-caryophyllene (Chahal et al., 2015). $\beta$-caryophyllene has also been widely suggested as a promising agent in cancer prevention and therapy. The anti-proliferative effects of $\beta$-caryophyllene on various cancer cell lines were reported by strong suppression of proliferation in two types of colon cancer cells (HCT-116 and HT-29) and of pancreatic cancer cells (PANC-1) (Dahham et al., 2015).

Our study aimed to determine the selectivity of VO effects against different types of cancer cells and identify the role and mechanism of $\beta$-caryophyllene to inhibit cancer progression. We used different types of cancer cells, which are $4 \mathrm{~T} 1$ cells (considered as a triple-negative model), T47D (expresses estrogen receptors), and WiDr cells (with p53 mutations and high expression of COX-2) which also known to have different levels of CNR2 expression. (Martínez-Martínez et al., 2016; Elbaz et al., 2017; Xiang et al., 2018). We used an approach based on physical characteristics and molecular analysis to determine the effect of $\beta$-caryophyllene containing VO toward each cell line and the correlation to CNR2. This result will support further explorations of $\beta$-caryophyllenecontaining essential oil as a chemopreventive agent.

\section{Materials and Methods}

Sample preparation and identification of the phytochemical profile

Vetiver (Chrysopogon zizanioides L.) obtained from Materia Medica Batu, Malang, Indonesia, has been identified. Vetiver rhizome weighing 500 grams was steam-distilled with $5 \mathrm{~L}$ of aquadest for $4 \mathrm{~h}$ in a Clevenger apparatus. The collected distillate was then added with anhydrous sodium sulfate to attract the water-in-oil footprint. Furthermore, VO was dissolved in methanol and then identified its phytochemical profile using Gas Chromatography-Mass Spectrometry (GC-MS) (Shimadzu) with Rtx 5 column, 30 meters long, helium carrier gas, and column temperature of $70-300^{\circ} \mathrm{C}$.

\section{Cell culture}

The WiDr colon cancer cells $\left(\mathrm{ATCC}^{\circledR} \mathrm{CCL}\right.$ TM 218) were obtained from the Cancer Chemoprevention Research Cancer collection, Faculty of Pharmacy, Universitas Gadjah Mada. TNBC 4T1 cells (ATCC ${ }^{\circledR}$ CRL-253) and luminal-type breast cancer T47D cells
(ATCC ${ }^{\circledR}$ HTB-133) were obtained from Professor Masashi Kawaichi, Nara Institute of Science and Technology, Japan. WiDr cells were grown in RPMI medium (Gibco), while 4T1 and T47D cells were grown in DMEM medium (Sigma) supplemented with FBS (Sigma) 10\% v/v and $1 \%$ penicillin-streptomycin (Sigma) at $37^{\circ} \mathrm{C}$ in $5 \% \mathrm{CO}_{2}$ humidified atmosphere and $95 \%$ air in a $\mathrm{CO}_{2}$ incubator.

\section{Cytotoxic assay}

WiDr cells $(8,000$ cells/well $), 4 \mathrm{~T} 1$ cells $(2,500$ cells/ well), and T47D cells $(5,000$ cells/well) were grown in 96 well plates and subjected to various concentrations of VO. After $24 \mathrm{~h}$ of incubation, the cell media was replaced and rinsed with PBS 1x, $5 \mathrm{mg} / \mathrm{mL}$ MTT reagent (Sigma) was added and incubated again for $4 \mathrm{~h}$. When formazan was formed, an SDS stopper was added, then incubated overnight. The absorbance was measured using an ELISA microplate reader (BioRad) at $595 \mathrm{~nm}$.

\section{Cell cycle analysis}

A density of $2 \times 10^{5}$ cells/well was planted on a 6-well plate and treated with various concentrations of VO, incubated for 24 hours. After cells were harvested, pellets were collected, washed with buffer solution, and stained with $1 \mathrm{mg} / \mathrm{mL}$ propidium iodide for cell cycle analysis (BD Cycletest ${ }^{\mathrm{TM}}$ Plus DNA Kit; BD Biosciences, San Jose, USA). The measurements were taken by an Accuri C6 (BD Bioscience) flow cytometer, and the data was analyzed with the BD C6 Software.

\section{Apoptosis assay}

A density of $2 \times 10^{5}$ cells/well was planted on a 6-well plate and treated with various concentrations of $\mathrm{VO}$, incubated for 24 hours. Cells were then harvested, pellets were collected, washed with buffer solution, and stained with the Annexin-V-FLUOS staining kit (Roche) for 10 minutes for cell cycle analysis (BD Cycletest ${ }^{\mathrm{TM}}$ Plus DNA Kit; BD Biosciences, San Jose, USA). The measurements were taken with an Accuri C6 (BD Bioscience) flow cytometer, and the data was analyzed with the BD C6 Software.

\section{Reactive Oxygen Species (ROS) intracellular assay}

WiDr, 4T1, and T47D cells were planted on 24 well plates at a $5 \times 10^{4}$ cells/well density. Cells were rinsed using Phosphate Buffer Saline (PBS) and $200 \mu \mathrm{L}$ of trypsin-EDTA $0.25 \%$ (Gibco). Followed by the addition of $500 \mu \mathrm{L}$ Supplemented Buffer (PBS containing Fetal Bovine Serum (FBS) 10\%) 1x, then the cell suspension was collected in a dark microtube and stained with 25 uM Dichlorodihydrofluorescein Diacetate (DCFDA),

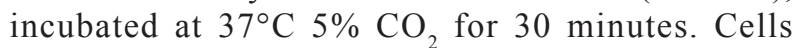
were treated with various concentrations of $\mathrm{VO}$ and Doxorubicin as a positive control for 4 hours. Using a BD Accuri C6 flow cytometer (BD Bioscience) with Ex 485 $\mathrm{nm} / \mathrm{Em} 535 \mathrm{~nm}$, measurements were taken by adjusting the number of 20,000 cells.

\section{Gene Expression and Survival Rate}

CNR2 and PPARA expression in breast cancer were analyzed through the UALCAN database with a BRCA 
dataset to obtain potential gene targets for further analysis. Expression was compared between normal versus tumor and normal versus major tumor subclasses in breast cancer. Correlation between survival rate and CNR2 and PPARA expression was analyzed through the OncoLnc database. Then, expression and survival rate data were re-visualized using GraphPad Prism 9 with boxplot and Kaplan-Meier plot, respectively.

\section{Molecular Docking}

Molecular docking was conducted using MOE 2010 (Licensed of Faculty of Pharmacy UGM) on CNR2 (PDB ID 5ZTY) as a potential target in breast cancer and GSK3B (PDB ID 3ZRM) as a potential target in colon cancer. The structure of small molecules was created using the Molecular Operating Environment (MOE) molecule builder (version 2010.10 licensed for Faculty of Pharmacy UGM) and then optimized using the MMFF94x force field and conformational search. Small molecules with the lowest docking score were collected, and protein-ligand interactions were analyzed.

\section{Data analysis}

All data collected in triplicate were analyzed through One Way ANOVA (IBM SPSS Statistics ver. 25) to identify the significant differences among the treatment.

\section{Results}

\section{Distillation and Identification of VO's Phytochemical Profile}

The distilled VO produced a yield of $0.032 \% \mathrm{w} / \mathrm{w}$, which was yellow in color and had a distinctive smell of vetiver. Phytochemical profile identification carried out by GC-MS showed 33 compounds, most of which were terpenoid compounds. The major active compound of VO was $\beta$-caryophyllene (peak 15) with an abundance of $15.43 \%$, which was indicated by $\mathrm{m} / \mathrm{z}=204$. In addition, nine other compounds had high abundance, namely biphenylene (peak 1), $\beta$-cedrene (peak 5), 2-carene (peak 8 ), cuminone (peak 14), ledane (peak 20), $\beta$-vetivenene (peak 21), $\alpha$-humulene (peak 22 and 24), myrcenol (peak 23), propanedinitrile (peak 26) (Figure 1). These results
Chemopreventive Property of Vetiver Oil Targets CNR2

confirmed the presence of $\beta$-caryophyllene, which was found to be very high in vetiver.

Interestingly, we realized that among the chemical compounds of $\mathrm{VO}$, we found at least ten compounds possessing biological effects related to cancer. Based on the analysis, $\beta$-vetivenene was thought to be the marker of VO's distinctive smell because it plays an essential role in the aroma characteristic of the oil. We then observed more deeply by literature studies among the ten compounds and their effects on cancer progression and evaluated the protein targets by Swiss-target prediction (Table 1). Most of the activities of VO were thought to come from the terpenoid group, which was known to have an extensive enough abundance that acts as a biomarker, namely $\beta$-caryophyllene (15.43\%). The main compound of VO, which was $\beta$-caryophyllene, was an agonist of phytocannabinoid and a cannabinoids-2 receptor (CB2)-selective. $\beta$-caryophyllene had similar activity to $\triangle 9$-tetrahydrocannabinol (THC) through activation of CNR2 receptors, leading to cell cycle arrest-induced apoptosis (Fidyt et al., 2016; Chung et al., 2019; Francomano et al., 2019; Arul et al., 2020). In line with this mechanism, another terpenoid compound, namely $\alpha$-humulene, which was anti-proliferative, pro-apoptotic, and had a strong anti-cancer effect when combined with 5-Fu and oxaliplatin (Ambrož et al., 2019; Chen et al., 2019). The cytotoxicity of VO was also due to the presence of biphenylene, $\beta$-cedrene, 2 -carene, ledane, and propanedinitrile (Pojarová et al., 2007a; Jeong et al., 2014; Batra et al., 2016; Salim et al., 2016; Elshamy et al., 2017). The results of this study revealed various potential effects associated with the inhibition or killing of cancer cells.

\section{Cytotoxic effect of $\mathrm{VO}$}

We then evaluated the cytotoxic effect of VO against cancer cell lines to figure out its selectivity on particular cancer cells. Cell proliferation profiles can be useful in understanding the mechanism of action of specific genes, proteins, and pathways involved in cell survival or death after exposure to toxic agents (Adan, Kiraz and Baran, 2016). We investigated this effect in three cell lines with different tissue origins and molecular markers, namely WiDr colon cancer cells expressing high levels of COX-2;

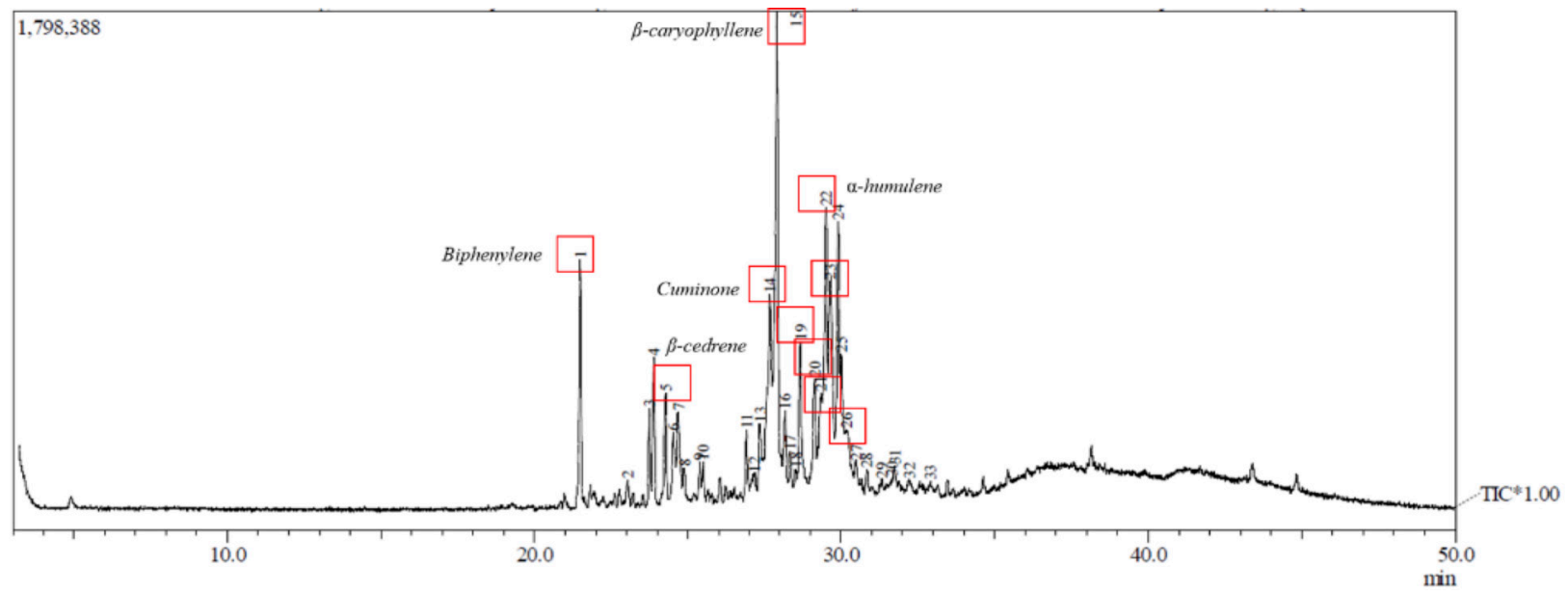

Figure 1. Phytochemical Content of VO. The GC-MS chromatogram of VO with methanol solvent was run with helium carrier gas using GCMS-QP2010S (SHIMADZU). 
Table 1. Main Compound of VO and Their Target Protein

\begin{tabular}{|c|c|c|c|c|c|}
\hline Peak & Compound & $\begin{array}{l}\text { Abundance } \\
(\%)\end{array}$ & KI & Activity & $\begin{array}{l}\text { Target protein based on } \\
\text { Swiss Target Prediction }\end{array}$ \\
\hline 1 & Biphenylene & 4.61 & 1357 & Cytotoxicity (Batra et al., 2016) & - \\
\hline 5 & $\beta$-cedrene & 2.27 & 1424 & - & HSD11B1 \\
\hline 14 & Cuminone & 8.85 & 1509 & - & $\begin{array}{l}\text { GSK3B, TYR, } \\
\text { IMPDH2, PTPN1, } \\
\text { TDO2, HSD11B1 }\end{array}$ \\
\hline 15 & $\beta$-caryophyllene & 15.43 & 1515 & $\begin{array}{l}\text { Synergistic anti-cancer effects with doxorubicin, } \\
\text { cytotoxicity, induction of apoptosis (Fidyt et al., } \\
\text { 2016; Hanušová et al., 2017; Ramachandhiran et } \\
\text { al., 2019) }\end{array}$ & $\begin{array}{c}\text { PPARA* }{ }^{*}, \mathrm{CNR} 2 * \\
\text { FAAH }\end{array}$ \\
\hline 19 & 2-carene & 4.3 & 1535 & Cytotoxicity (Liu et al., 2017) & $\begin{array}{c}\text { PPARA, CNR2, FAAH, } \\
\text { AR, ESR1, CHRM2 }\end{array}$ \\
\hline 20 & Ledane & 3.6 & 1546 & - & PPARA, CNR2 \\
\hline 21 & $\beta$-vetivenene & 3.62 & 1552 & Antioxidant (Kim et al., 2005) & $\begin{array}{c}\text { ADORA1, ADORA2A, } \\
\text { AR, ESR1, ESR2 }\end{array}$ \\
\hline 22 & $\alpha$-humulene & 8.12 & 1556 & $\begin{array}{l}\text { Synergistic anti-cancer effect with 5-FU and } \\
\text { oxaliplatin; antiproliferation and apoptosis } \\
\text { induction (Ambrož et al., 2019; Chen et al., 2019) }\end{array}$ & PPARA, CNR2 \\
\hline 23 & Myrcenol & 8.52 & 1560 & - & $\begin{array}{l}\text { PTGS1, HSD11B1, } \\
\text { SIGMAR1, DRD2, AR, } \\
\text { HSD17B2 }\end{array}$ \\
\hline 26 & Propanedinitrile & 3.54 & 1574 & Cytotoxicity (Seckl and Rozengurt, 1996) & - \\
\hline
\end{tabular}

*, probability above $50 \%$.

4T1 breast cancer cells categorized as TNBC; and T47D breast cancer cells that express estrogen receptors. The VO treatment resulted in different $\mathrm{IC}_{50}$ values, which were 302 $\mu \mathrm{g} / \mathrm{mL}, 60 \mu \mathrm{g} / \mathrm{mL}$, and $112 \mu \mathrm{g} / \mathrm{mL}$, respectively (Figure 2). These results indicated that $4 \mathrm{~T} 1$ was the most sensitive to VO treatment while WiDr was the most resistant. We may note that VO most likely preferred to be against breast cancer cells rather than colon cancer cells, and the TNBC sub-type was more suitable than the luminal subtype. This difference in response was probably caused by the distinctive expressions of protein markers that may affect the physiological process of each type of cell line.

\section{Cell Cycle Inhibition of VO}

The cell cycle is the main physiological process in cancer cells in which the cells undergo proliferation over the limit of cell division number. This mechanism is supported by protein kinases called cyclin-dependent kinases (CDKs), which control the activity of kinase and are only active when bound by a specific regulation component, "cycline," with serine/threonine-specific catalytic core (Shah et al., 2020). Cytotoxic drugs can stop cell proliferation by abrogating cell cycle machinery resulting in cell cycle arrest or cell death. Interestingly $\mathrm{VO}$ treatment showed different phenomena among the three cell types. VO treatment caused cell cycle arrest in

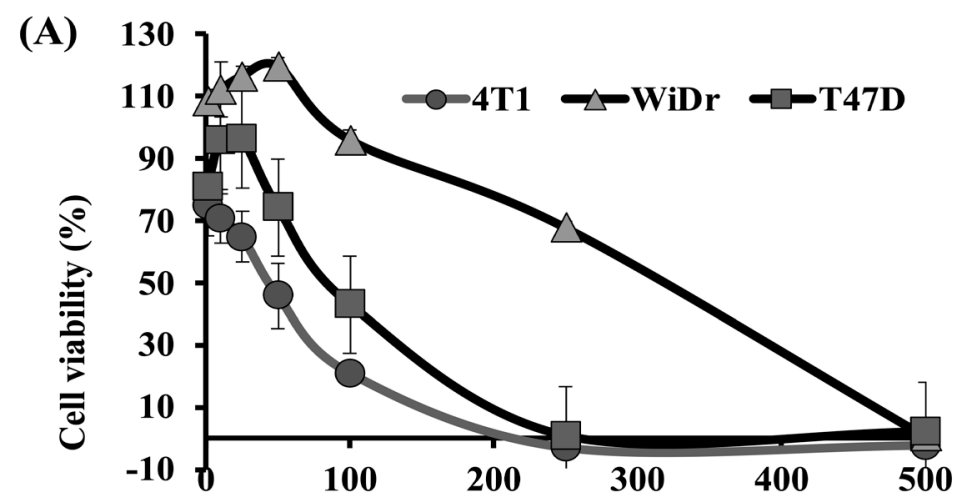

(B)

\begin{tabular}{cc}
\hline Cell lines & IC $_{\mathbf{5 0}}(\boldsymbol{\mu g} / \mathbf{m L})$ \\
\hline WiDr & 302 \\
$4 T 1$ & 62 \\
T47D & 112 \\
\hline
\end{tabular}

\section{VO $(\mu \mathrm{g} / \mathbf{m L})$}

Figure 2. Cytotoxicity of VO on WiDr, 4T1, and T47D cells. Cells $\left(8 \times 10^{3} \mathrm{WiDr}\right.$ cells/well, $2,5 \times 10^{3} 4 \mathrm{~T} 1$ cells/well, $5 \times 10^{3}$ T47D cells/well) were treated with VO $1-500 \mu \mathrm{g} / \mathrm{mL}$ for 24 hours, then cell viability measured by MTT assay using linear regression $(\mathrm{p}<0.05)$. (A) The cell viability profiles of WiDr, 4T1, and T47D with VO treatments. (B) The comparison table of $\mathrm{IC}_{50}$ values after $\mathrm{VO}$ treatments. 

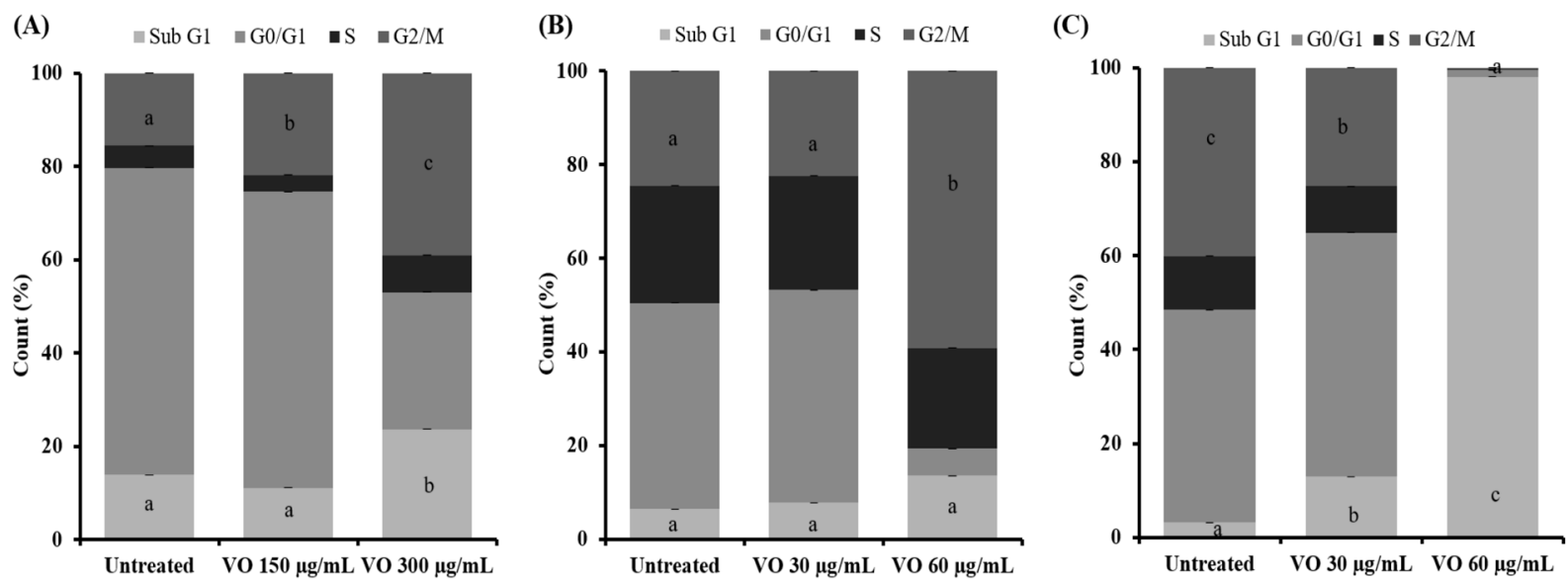

Figure 3. Profile of Cell Cycle Inhibition after VO Treatment. WiDr (A), 4T1 (B), and T47D (C) cells were planted $2 \times 10^{5}$ cells $/ \mathrm{mL}$ on 6 -well plates then incubated for 24 hours. Cells were harvested after being treated with VO 150 \& $300 \mu \mathrm{g} / \mathrm{mL}$ on WiDr cells and VO $30 \& 60 \mu \mathrm{g} / \mathrm{mL}$ on $4 \mathrm{~T} 1$ and T47D cells. Then the cells were stained with propidium iodide and read with a flow cytometer. The error bar shows a representation of the standard error $(\mathrm{n}=3)$. Different characters $(\mathrm{a}-\mathrm{c})$ are the known significance through the Bonferroni test $(\mathrm{p}<0.05)$ compared to control cells.

different phases, known from the experimental results that WiDr cells and 4T1 cells underwent arrest in the G2/M phase $(\mathrm{p}<0.01)$ (Figure 3). However, VO treatment on T47D increased sub G1 population $(\mathrm{p}<0.01)$, while $4 \mathrm{~T} 1$ cells did not increase significantly compared to controls. These results indicated that the G2/M arrest was stronger in $4 \mathrm{~T} 1$ cells. Meanwhile, treatment of VO on T47D cells gave no differences in $\mathrm{G} 1$ phase cells accumulation between the control and VO $30 \mu \mathrm{g} / \mathrm{mL}$. Moreover, cell death induction was found after treatment of 30 and 60 $\mu \mathrm{g} / \mathrm{mL}$ of $\mathrm{VO}$.

\section{Apoptosis Effect of VO}

Apoptosis results in fragmentation of the cell nucleus genome. It has a vital role in eradicating cancer cells and is an essential target in discovering anti-cancer drugs (Meiyanto et al., 2019). To clarify whether the cell cycle arrest effect under VO treatments is correlated with apoptosis phenomena, we then carried out flow cytometry analysis with PI staining on VO treated cells. Flow cytograms confirmed that the treatment of $\mathrm{VO}$ at the concentration 30 and $60 \mu \mathrm{g} / \mathrm{mL}$ increased apoptosis in WiDr and T47D cells $(\mathrm{p}<0.01)$, while in $4 \mathrm{~T} 1$ cells, VO treatment did not induce apoptosis (Figure 4). These findings lead us to give more attention to the molecular events that underlie the phenomena.

\section{ROS scavenging system of $V O$}

In general, cell cycle arrest and apoptosis are attributed to ROS levels in cells. Free radicals cause carcinogenesis and tumor cell progression, which are the characteristics of cancer cells. In cancer cells, low to medium intracellular ROS level plays a role in promoting cell proliferation. A high intracellular ROS level in normal cells causes oxidative DNA damage and leads to cancer formation and cell death. ROS plays an essential role at each stage of cancer cell development, namely in initiation, promotion, and progression. Increased intracellular ROS level leads to an activation of oncogene and inactivation of tumor suppressor genes, angiogenesis, and mitochondrial dysfunction (Kumari et al., 2018; Larasati et al., 2018). Our data revealed that
(A)

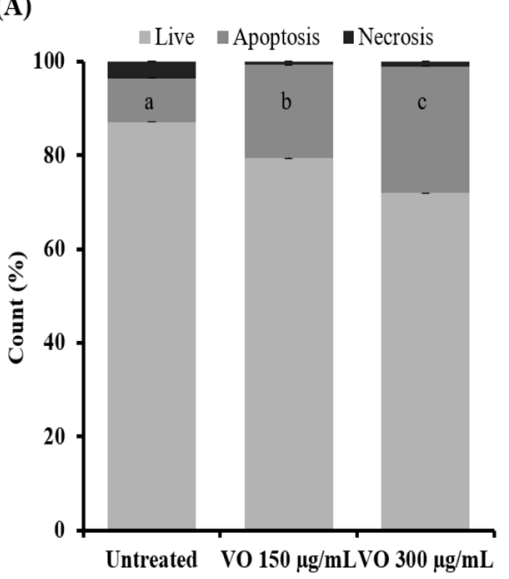

(B)

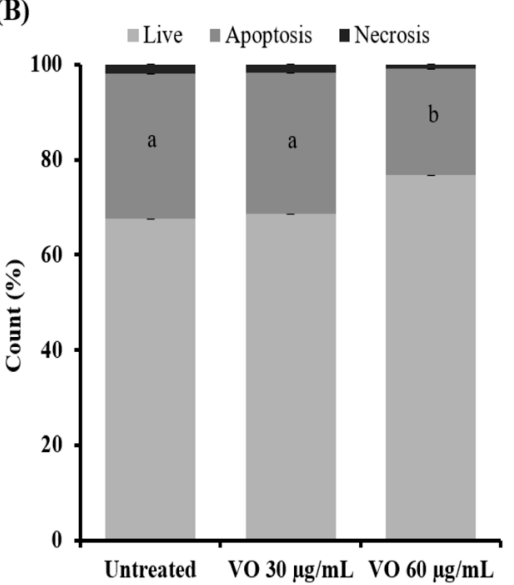

(C)

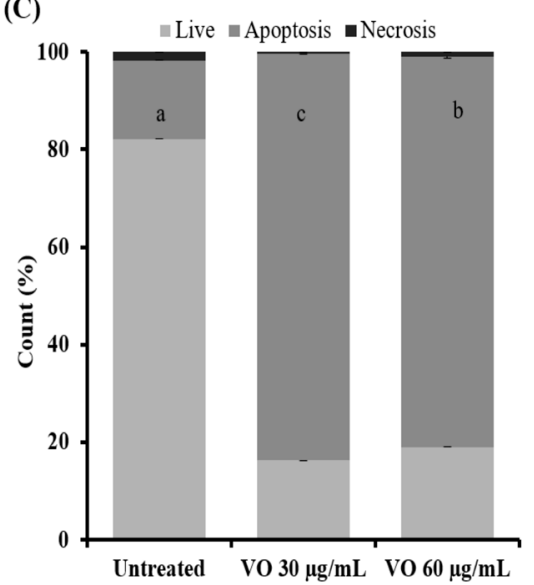

Figure 4. Apoptotic effects of VO Treatment. WiDr (A), 4T1 (B), and T47D (C) cells $\left(2 \times 10^{5}\right.$ cells $\left./ \mathrm{mL}\right)$ were treated with VO 150 and $300 \mu \mathrm{g} / \mathrm{mL}$ subjected to Apoptotic detection with Annexin V/PI staining with a flow cytometer $(\mathrm{n}=$ $3)$. Different characters $(a-c)$ represent different values significantly $(p<0.01)$. 

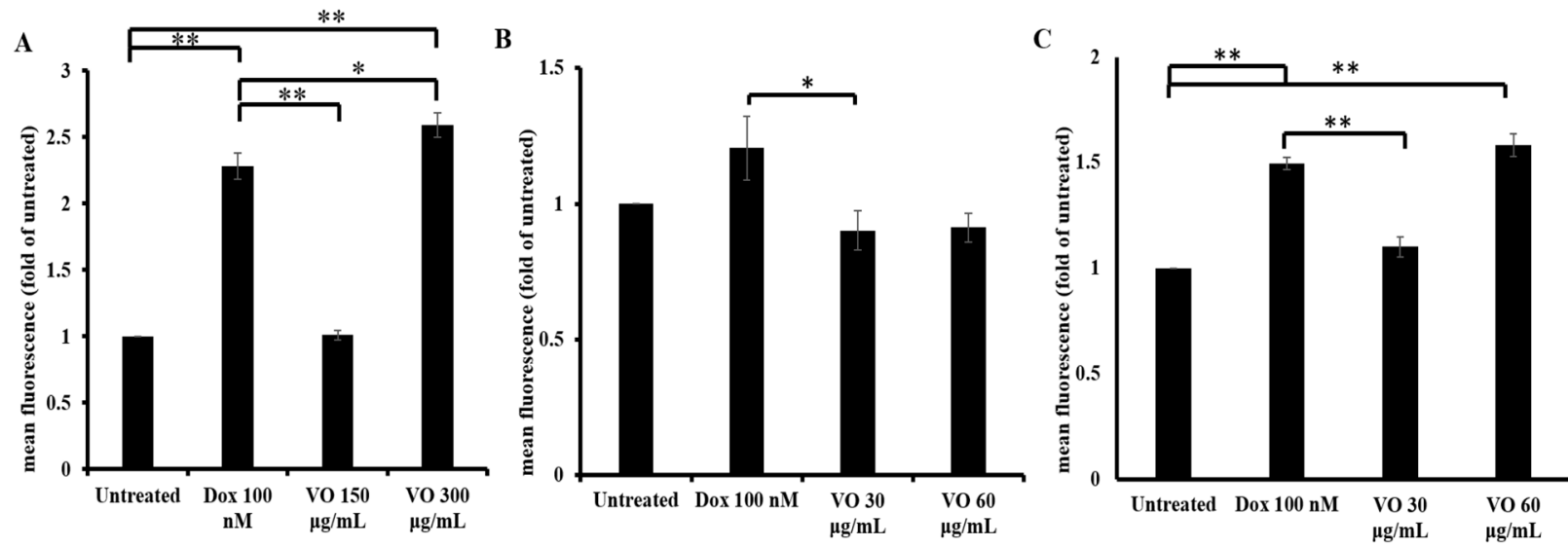

Figure 5. Effect of VO Treatment on Intracellular ROS Level. Intracellular ROS Level of VO treatment with DCFDA staining assay. WiDr, 4T1, and T47D cultured cells $\left(5 \times 10^{4}\right.$ cells $\left./ \mathrm{mL}\right)$ were treated with VO $(150$ and $300 \mu \mathrm{g} / \mathrm{mL} ; 30$ and $60 \mu \mathrm{g} / \mathrm{mL}$ ) for $4 \mathrm{~h}$ before being subjected to ROS detection with DCFDA staining using flow cytometry $(\mathrm{n}=3)$ with doxorubicin as the positive control. (A) ROS level profile of WiDr cells (B) ROS level profile on 4T1 cells (C) ROS level profile of T47D cells. The significant differences among the treatments were analyzed using one-way ANOVA, $* \mathrm{P}<0.05, * * \mathrm{P}<0.01$.

ROS levels were increased significantly in WiDr and T47D cells but not in 4T1 cells (Figure 5). This phenomenon makes sense with the effect of VO treatment on cell cycle progression and apoptosis. VO's apoptosis induction effect on WiDr and T47D is likely correlated with the increase of intracellular ROS. Hence, intracellular ROS seems to contribute to the molecular events of apoptosis. However, the phenomenon of cell cycle arrest of 4T1 cells might be triggered by other mechanisms.

\section{Gene Expression and Survival Rate Analysis}

We then analyzed the protein target that underlies these compounds to have anti-cancer activity. The results of our analysis with the Swiss Target Prediction showed that among the proteins that appeared, two proteins were likely to mediate the various effects seen, namely Cannabinoid CB2 receptor (CNR2) and peroxisome proliferatoractivated receptor alpha (PPARA). Both proteins have a probability above $50 \%$, so that it is very potential if used as targets. Interestingly, we found estrogen receptors (ESR1 and ESR2) as markers of T47D cells and GSK3B as markers of expressed WiDr cells. Therefore, we next analyzed the CNR2 and PPARA expression levels on luminal, TNBC, and colon cancer cells to determine precisely what causes the differences in activities between these cells.

TNBC cells expressed CNR2 and PPRA proteins significantly higher than normal cells $(p<0.01)$ (Figure 6A). Luminal cells expressed both proteins in the same level as normal cells ( $p>0.01)$. Meanwhile, colon cancer

\section{CNR2}

(A)

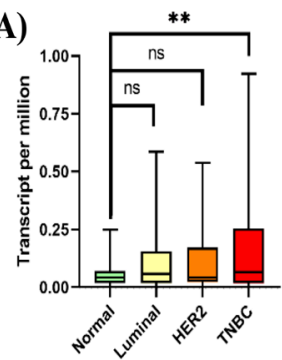

(B)

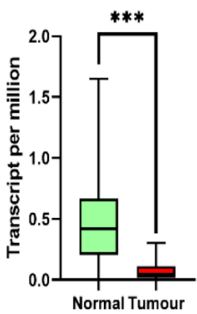

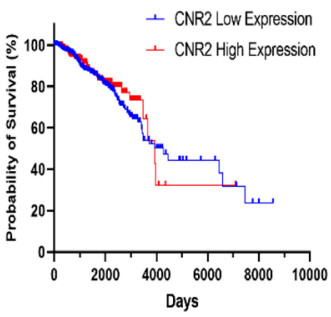

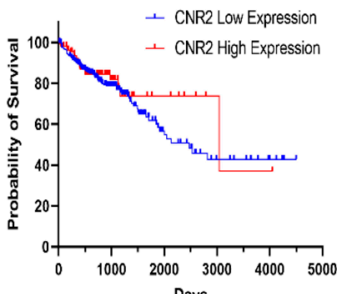

PPARA
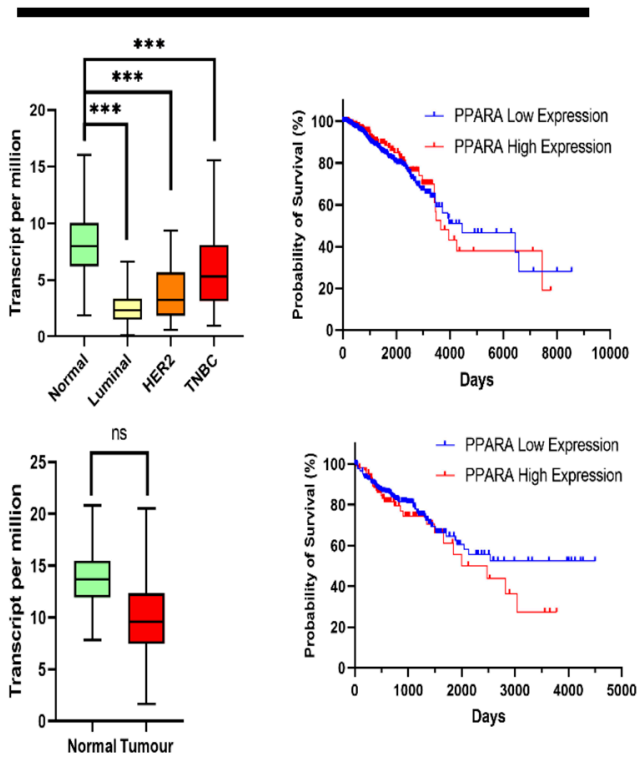

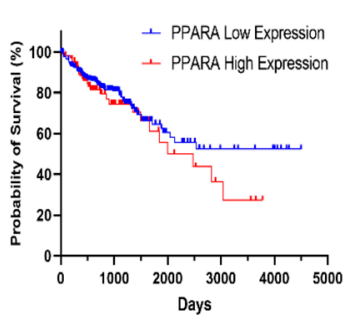

Figure 6. Target Gene Expression and Survival Rates. Data on gene expression and probability of survival were observed in two cancer types, namely breast cancer with the luminal subtype, HER2, TNBC, and colon cancer, obtained from the UALCAN database. (A) CNR2 and PPARA in breast cancer, (B) CNR and PPARA in colon cancer. 
(A)
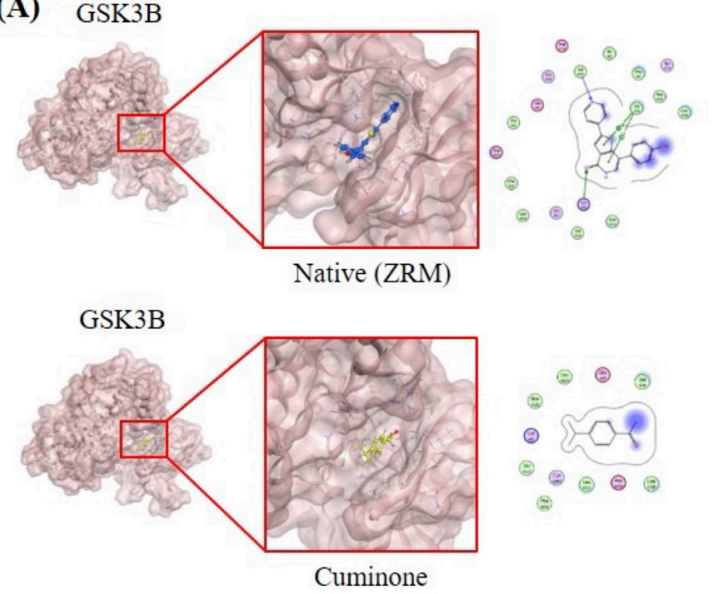

Cuminone

\begin{tabular}{|c|c|c|c|}
\hline $\begin{array}{l}\text { Target } \\
\text { protein } \\
\text { (PDB ID) }\end{array}$ & Ligand & $\begin{array}{l}\text { RMSD } \\
(\hat{\boldsymbol{A}})\end{array}$ & $\begin{array}{l}\text { Docking score } \\
\text { (kcal/mol) }\end{array}$ \\
\hline \multirow[t]{2}{*}{$\begin{array}{l}\text { GSK3B } \\
(3 Z R M)\end{array}$} & $\begin{array}{l}\text { Native ligand } \\
(\mathrm{ZRM})\end{array}$ & 0.8588 & -8.5836 \\
\hline & Cuminone & - & -7.5592 \\
\hline \multirow{5}{*}{$\begin{array}{l}\text { CNR2 } \\
\text { (5ZTY) }\end{array}$} & Native ligand (9JU) & 1.075 & -12.0557 \\
\hline & $\beta$-caryophyllene & - & $-8,7228$ \\
\hline & a-humulene & - & -8.8885 \\
\hline & Bicine (agonist) & - & -7.8815 \\
\hline & $\begin{array}{l}\text { Palmitoleic acid } \\
\text { (antagonist) }\end{array}$ & - & -11.7818 \\
\hline
\end{tabular}

(C)
(B)
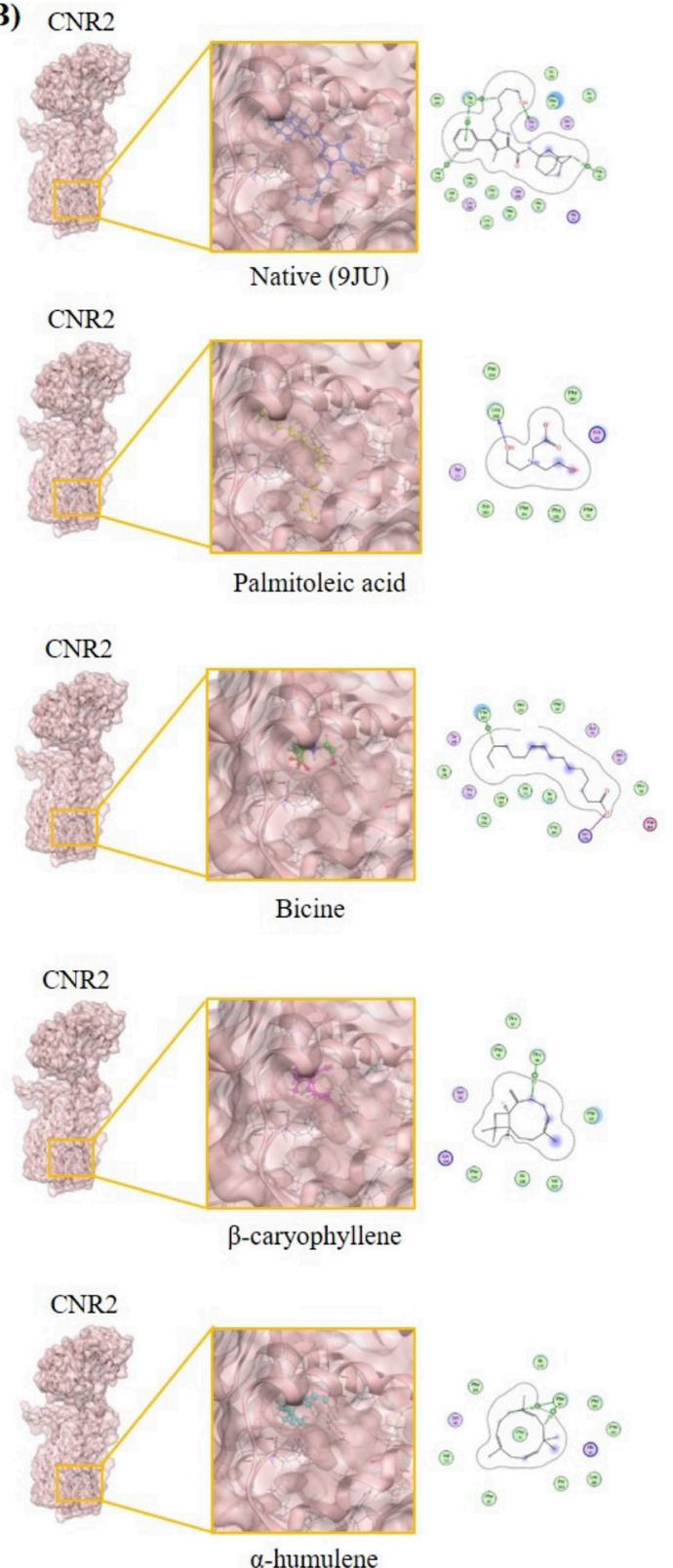

Figure 7. Molecular Docking. Docking visualization was performed on (A) GSK3B with native and cuminone, and (B) CNR2 with native, palmitoleic acid (CNR2 antagonist), bicine (CNR2 agonist), $\beta$-caryophyllene, $\alpha$-humulene. This approach is strengthened by $(\mathrm{C})$ molecular docking score table, which indicates the stability of the interaction.

cells showed a very low expression level of both proteins, even lower than controls (Figure 6B). Therefore, it is necessary to look further based on the survival rate of CNR2 and PPARA, which showed that CNR2 and PPARA had a poor survival probability with an endpoint of fewer than 8,000 days.

These findings may be related to the lower $\mathrm{IC}_{50}$ value of $4 \mathrm{~T} 1$ cells and the sensitivity of the others. Meanwhile, the colon is not the target of CNR2, so it may tend to lead to GSK3B because it has high expression in the colon, but unfortunately, the probability is low, which is still below 50\%. Likewise, T47D cells, which have ESR1 and ESR2, also have a high expression with low probability. Another confirmation was evidenced by molecular docking, where the docking scores between the CNR2 and $\beta$-caryophyllene ligands were equally low, supported by an RMSD value below 2 . This result provides a bright insight into why the effect is not as strong as on 4T1 cells. Nevertheless, we still need to observe further to determine the pathways that elicit the activity by molecular docking.

\section{Molecular Docking}

Molecular docking was used to obtain the binding affinities described with docking scores ( $\mathrm{kcal} / \mathrm{mol}$ ) between ligand and protein. This study examined the binding affinities of $\beta$-caryophyllene and $\alpha$-humulene with cannabinoid receptor 2 (CNR2) as the potential target in breast cancer. We also subjected bicine and palmitoleic acid as agonists and antagonists to CNR2, respectively. Compared to each ligand, palmitoleic acid (antagonist) had a lower docking score, and bicine (agonist) had a higher docking score (Fig. 7). We could hypothesize that the lower 


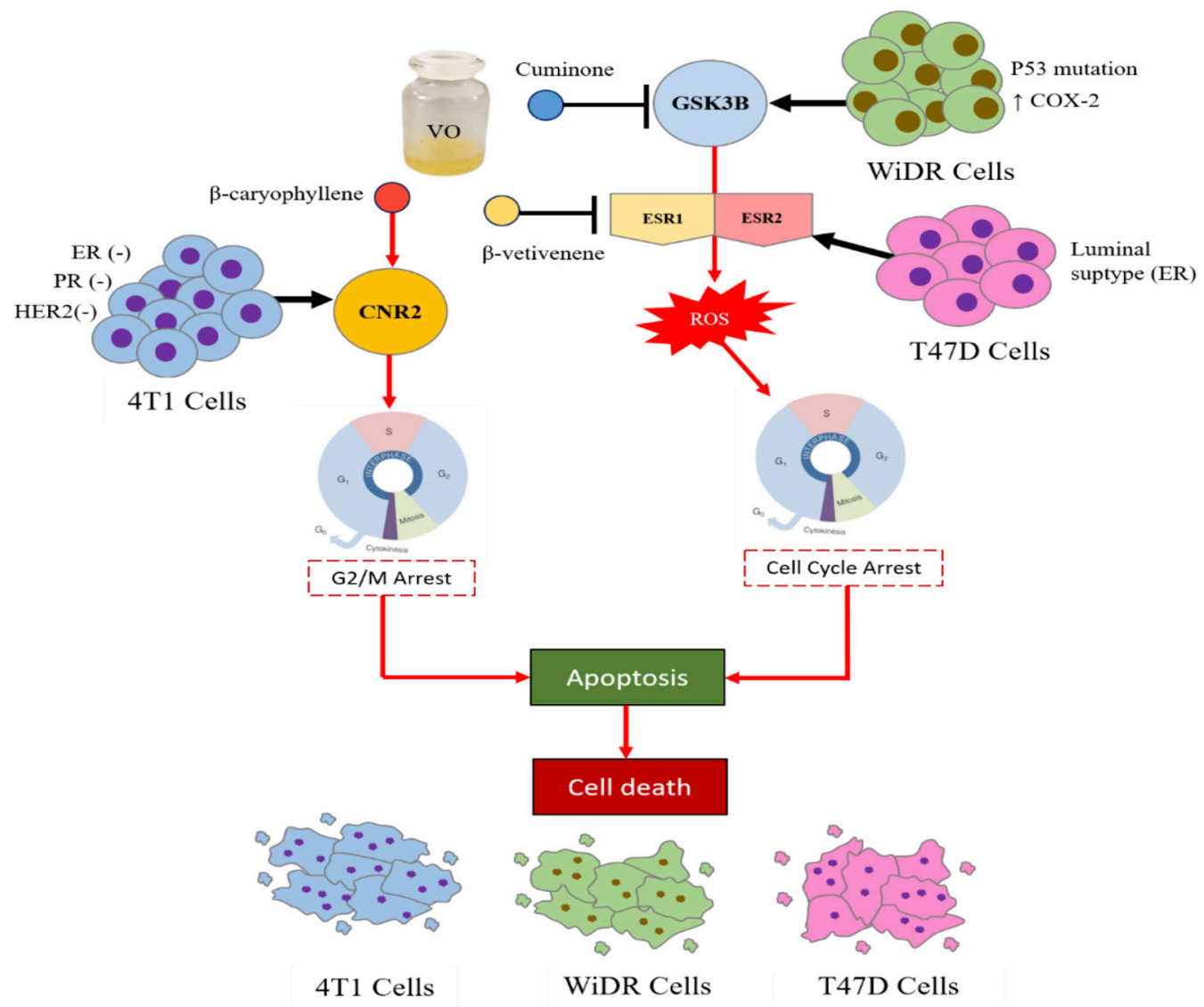

Figure 8. The Mechanism of VO's Effects on WiDr, 4T1, and T47D cells. VO contained $\beta$-caryophyllene which targeted CNR2 on 4T1 cells leading to cell cycle arrest and apoptosis. While cuminone targeted GSK3B on WiDr cells leading to ROS generation and cell cycle arrest.

the docking score, the more likely the ligand is to have an antagonist activity. $\alpha$-humulene was more likely to have an antagonist activity compared to $\beta$-caryophyllene. The native ligand 9JU performed the lowest docking score of $-12.056 \mathrm{kcal} / \mathrm{mol}$, which had a direct bond with the amino acids Phenylalanine94, Trptophan194, Trptophan258, and Threonine114 (Figure 7). The VO metabolites, namely $\beta$-caryophyllene and $\alpha$-humulene, both were bound to phenylalanine94 with not much different docking scores, namely $-8.72 \mathrm{kcal} / \mathrm{mol}$ and $-8.89 \mathrm{kcal} / \mathrm{mol}$, respectively. On the other hand, Bicine (CNR2 agonist) was bound to Lysine109 and Phenylalanine183 while Palmitoleic acid (CNR2 antagonist) was bound to Leucine182. The amino acid interactions between native ligands, CNR2 agonists, respective CNR2 antagonists, and their respective VO metabolites indicated the potential of $\mathrm{VO}$ as a new candidate targeting CNR2. We also conducted molecular docking to glycogen synthase kinase 3 beta (GSK3B) as the potential target in colon cancer. Compared to the native ligand (ZRM), cuminone had a lower docking score than the native ligand. This possibility occured because cuminone did not show a direct interaction with the amino acid GSK3B while the native ligand interacted with Valine70 Lysine85 Valine135

\section{Discussion}

The purpose of this study was to explore vetiver oil (VO) potential to inhibit the activity of cancer development based on in vitro and in silico studies. Bioinformatics analyses were also carried out to determine the specific target proteins thought to mediate these effects. We used two breast cancer cells, namely luminal type A that expressed ER+ (T47D cells), triple-negative breast cancer or TNBC cell line (4T1 cells), and colon cancer cells that are characterized with a high COX-2 expression (WiDr cells).

The different characteristics of the three cells that we used provide different responses for each cell (Figure 8). The first anti-cancer study evaluated was the degree of cytotoxicity. VO cytotoxicity showed that VO treatment had the highest $\mathrm{IC}_{50}$ value in WiDr cells and the lowest in $4 \mathrm{~T} 1$ cells. A low $\mathrm{IC}_{50}$ value below $100 \mu \mathrm{g} / \mathrm{mL}$ generally indicates a strong and highly sensitive anti-cancer potential (Prayong, Barusrux, and Weerapreeyakul, 2008). Looking closer at the other breast cancer cells, T47D cells showed an $\mathrm{IC}_{50}$ value above $100 \mu \mathrm{g} / \mathrm{mL}$, indicating that $\mathrm{VO}$ was weakly toxic to T47D cancer cells. This effect was also observed in WiDr cells. This result provides knowledge that VO has a good target for 4T1 breast cancer cells and can be projected as an anti-cancer agent.

Further confirmation on the anti-cancer effect was obtained through the cell death analysis. WiDr and 4T1 cells were in G2/M arrest, but interestingly, apoptosis was only observed in WiDr and T47D cells, whereas in $4 \mathrm{~T} 1$ cells, there were none of the phenomena compared to controls. G2/M arrest can be caused by the failure of the cell mitotic phase, which in turn will lead to apoptosis 
and cell death (Pojarová et al., 2007b).

Cell death pathways can also be observed through intervening intracellular ROS metabolic rate. Intracellular ROS level that exceeds the threshold will eventually be toxic for cells (Larasati et al., 2018). Hence, to trigger cancer cell death, agents that can increase ROS levels are needed (Ahlina et al., 2020). Our study showed a significant increase in ROS levels in WiDr and T47D cells; this result corresponds with the previous analysis that showed how both cell lines experienced cell death due to changes in cellular metabolism after VO treatments.

Interestingly, 4T1 cells exhibited different results from the previous two cells. There was no increase in apoptotic cells and intracellular ROS levels compared to controls, making it hard to precisely predict how the mechanism mediates the previously described toxicity. In this study, we only carried out a new look at how the effects occurred during the 24 hours of testing. The effect of TNBC cell death may be obtained if the observation time is extended.

We did not stop there and tried to find other ways that caused this event. Recognizing that the major compounds of $\mathrm{VO}$ have various properties with diverse mechanisms of action provided us with a glimmer of insight (Table 1). Based on that fact, the metabolic pathways taken by cancer cells after $\mathrm{VO}$ administration were very interesting to be studied further, which would involve specific target proteins. CNR2 was found to have a higher expression than PPARA in all breast cancer cell lines (Figure 6). This prediction matched with a previous study, which revealed that CNR2 was responsible for breast cancer cells (Brown et al., 2020). In addition, CNR2 is also highly expressed in various cancer tissues.

We compared native ligands, bicine agonists, and palmitoleic acid antagonists from CNR2 to obtain compounds that can bind to CNR2 ligands selectively to determine the cause of the cancer-inhibiting effect. Compounds $\beta$-caryophyllene and $\alpha$-humulene performed docking scores close to bicine, making them potential phytocannabinoids (Figure 7). Previous studies have reported that $\beta$-caryophyllene functions as phytocannabinoids, but there is no evidence for $\alpha$-humulene. Our study provides an overview of the synergistic effect of the two phytocannabinoids on CNR2, which mediates the inhibition of cancer malignancy (Figure 8).

In colon cancer, CNR2 is not the main marker for the survival rate due to the low expression level while some are not expressed (Martínez-Martínez et al., 2016) (Figure 6). This finding on colon cancer turns the target to GSK3B protein because it is known for its high expression (Dupasquier et al., 2019; Wu et al., 2019; Evangelisti et al., 2020). GSK3B is one of the critical predictive targets that have a role in developing colorectal cancer through the intracellular signaling cascade and phosphorylation, so we pay attention to this finding (Wulandari et al., 2020). Based on this study, the prediction of GSK3B interaction with cuminone compounds from $\mathrm{VO}$ was stronger than native ligands (Figure 7). It can be predicted that cell death in WiDr colon cancer cells was caused by the presence of cuminone in VO (Figure 8).

These findings revealed a great potential of $\mathrm{VO}$ as an anti-cancer agent. VO was confirmed to be safe against normal cells by the result of the cytotoxicity test against NIH-3T3 cells, which are fibroblast cell lines representing normal cells (Jenie et al., 2021; Zulfin et al., 2021). Cytotoxicity to NIH-3T3 was considered to be low cytotoxic with an $\mathrm{IC}_{50}$ value of $266 \mu \mathrm{g} / \mathrm{mL}$ (data not shown). These interesting results are expected to open up opportunities for developing $\mathrm{VO}$ as an anti-cancer agent of the colon and co-chemotherapeutic agent to increase the effectiveness of chemotherapy agents that often experience resistance problems.

In conclusion, $\mathrm{VO}$ gave different cytotoxic effects on 4T1, T47D, and WiDr cells, and 4T1 cells were the most sensitive to VO. VO in WiDr and 4T1 cells caused cell cycle arrest in the G2/M phase, while in T47D cells, it caused cell accumulation in the subG1 phase. The most responsible compounds for these effects are $\beta$-caryophyllene and $\alpha$-humulene, which specifically affect TNBC, targeted on CNR2.

\section{Abbreviations}

ROS: reactive oxygen species

TNBC: triple-negative breast cancer

DCFDA: 2',7'-Dichlorodihydrofluorescein diacetate CNR2: cannabinoids $\mathrm{CB} 2$ receptor

PPARA: peroxisome proliferator-activated receptor alpha

GSK3B: glycogen synthase kinase 3 beta

MAPK: mitogen-activated protein kinase

PI3K: phosphoinositide 3-kinase

COX-2: cyclooxygenase-2

PGE-2: prostaglandin E-2

\section{Author Contribution Statement}

EM designed the study and proof outline. MH, RW, $\mathrm{UMZ}, \mathrm{SH}$ carried out the laboratory works. MH, RW, $\mathrm{UMZ}, \mathrm{EPN}$ analyzed the data and editing. EM, MH prepared and finishing the manuscript. All authors have read and approved the final version of the manuscript.

\section{Acknowledgments}

We thank CCRC, Faculty of Pharmacy, Universitas Gadjah Mada for the main support of this research.

\section{Conflict of interest}

We declare that we do not have a conflict of interest.

\section{References}

Adan A, Kiraz Y, Baran Y (2016). Cell proliferation and cytotoxicity assays. Curr Pharm Biotechnol, 17, 1213-21.

Ahlina FN, Nugraheni N, Salsabila IA, et al (2020). Revealing the reversal effect of Galangal (Alpinia galanga L.) Extract against oxidative stress in metastatic breast cancer cells and normal fibroblast cells intended as a co- chemotherapeutic and anti-ageing agent. Asian Pac J Cancer Prev, 21, 107-17.

Ambrož M, Šmatová M, Šadibolová M, et al (2019). Sesquiterpenes $\alpha$-humulene and $\beta$-caryophyllene oxide enhance the efficacy of 5-fluorouracil and oxaliplatin in colon cancer cells. Acta Pharm, 69, 121-8.

Asian Pacific Journal of Cancer Prevention, Vol 23 
Arul S, Rajagopalan H, Ravi J, Dayalan H (2020). BetaCaryophyllene suppresses ovarian cancer proliferation by inducing cell cycle arrest and apoptosis. Anti-cancer Agents Med Chem, 20, 1530-7.

Brown I, Lee J, Sneddon AA, et al (2020). Anti-cancer effects of n-3 EPA and DHA and their endocannabinoid derivatives on breast cancer cell growth and invasion. Prostaglandins Leukot Essent Fatty Acids, 156, 102024.

Chahal KK, Bhardwaj U, Kaushal S, Sandhu AK (2015). Chemical composition and biological properties of Chrysopogon zizanioides Chemical composition and biological properties of Chrysopogon zizanioides (L .) Roberty syn . Vetiveria zizanioides ( L .) Nash- A Review. Indian J Nat Prod Resour, 6, 251-60.

Chen H, Yuan J, Hao J, Wen Y (2019). $\alpha$-humulene inhibits hepatocellular carcinoma cell proliferation and induces apoptosis through the inhibition of Akt signaling. Food Chem Toxicol, 134, 110830.

Chung KS, Hong JY, Lee JH, et al (2019). $\beta$-caryophyllene in the essential oil from chrysanthemum boreale induces $\mathrm{G} 1$ phase cell cycle arrest in human lung cancer cells. Molecules, 24, 3754.

Dahham SS, Tabana YM, Iqbal MA, et al (2015). The anti-cancer, antioxidant and antimicrobial properties of the sesquiterpene $\beta$-caryophyllene from the essential oil of Aquilaria crassna. Molecules, 20, 11808-29.

Dhopeshwarkar A, Mackie K (2014). CB 2 Cannabinoid Receptors as a Therapeutic Target-What Does the Future Hold?. Mol Pharmacol, 86, 430-437.

Dupasquier S, Blache P, Lasorsa LP, et al (2019). Modulating PKC $\alpha$ activity to target $\mathrm{Wnt} / \beta$-catenin signaling in colon cancer. Cancers, 11, 693.

Elbaz M, Ahirwar D, Ravi J, Nasser MW, Ganju RK (2017). Novel role of cannabinoid receptor 2 in inhibiting EGF/ EGFR and IGF-I/IGF-IR pathways in breast cancer. Oncotarget, 8, 29668-29678.

Elshamy AI, El-Kashak WA, Abdallah HMI, Farrag AH, Nassar MI (2017). Soft coral Cespitularia stolonifera: New cytotoxic ceramides and gastroprotective activity. Chin J Nat Med, $15,105-114$.

Evangelisti C, Chiarini F, Paganelli F, et al (2020). Crosstalks of GSK3 signaling with the mTOR network and effects on targeted therapy of cancer. Biochim Biophys Acta Mol Cell Res, 1867, 118635.

Feng R, Tong Q, Xie Z, et al (2015). Targeting cannabinoid receptor-2 pathway by phenylacetylamide suppresses the proliferation of human myeloma cells through mitotic dysregulation and cytoskeleton disruption: Anti-Myeloma Effect of Targeting CB2. Mol Carcinog, 54, 1796-1806.

Fidyt K, Fiedorowicz A, Strządała L, Szummy A (2016). $\beta$-caryophyllene and $\beta$-caryophyllene oxide-natural compounds of anti-cancer and analgesic properties. Cancer Med, 5, 3007-3017.

Francomano F, Caruso A, Barbarossa A, et al (2019). $\beta$-caryophyllene A Sesquiterpene with Countless Biological Properties. Appl Sci, 9, 5420.

Hanlon KE, Lozano-Ondoua AN, Umaretiya PJ, et al (2016). Modulation of breast cancer cell viability by a cannabinoid receptor 2 agonist, JWH-015, is calcium-dependent. Breast Cancer Targets Ther, 8, 59-71.

Hanušová V, Caltová K, Svobodová H, et al (2017). The effects of $\beta$-caryophyllene oxide and trans-nerolidol on the efficacy of doxorubicin in breast cancer cells and breast tumorbearing mice. Biomed Pharmacother, 95, 828-36.

Hinz B, Ramer R (2019). Anti-tumour actions of cannabinoids: Anti-tumour actions of cannabinoids. Br J Pharmacol, 176, 1384-94.
Jenie R, Utomo RY, Susidarti RA, et al (2021). The Evaluation of Cytotoxic Properties from CCB-2 Sugar Complexes Against TNBC and Non-TNBC Cells. Asian Pac J Cancer Prev, 22, 151-5.

Jeong HU, Kwon SS, Kong TY, Kim JH, Lee HS (2014). Inhibitory effects of cedrol, $\beta$-cedrene, and thujopsene on cytochrome P450 enzyme activities in human liver microsomes. Toxicol Environ Health Sci, 77, 1522-32.

Khan MI, Sobocińska AA, Brodaczewska KK, et al (2018). Involvement of the CB2 cannabinoid receptor in cell growth inhibition and G0/G1 cell cycle arrest via the cannabinoid agonist WIN 55,212-2 in renal cell carcinoma. BMC Cancer, 18, 1-17.

Kim HJ, Chen F, Wang X, Chung HY, Jin Z (2005). Evaluation of antioxidant activity of vetiver (Vetiveria zizanioides L.) oil and identification of its antioxidant constituents. J Agric Food Chem, 53, 7691-75.

Kisková T, Mungenast F, Suváková M, Jäger W, Thalhammer $\mathrm{T}$ (2019). Future aspects for cannabinoids in breast cancer therapy. Int J Mol Sci, 20, 1673.

Kumari S, Badana AK, G MM, G S, Malla R (2018). Reactive Oxygen Species: A Key Constituent in Cancer Survival. Biomark Insights, 13, 1-9.

Larasati YA, Yoneda-Kato N, Nakamae I, et al (2018). Curcumin targets multiple enzymes involved in the ROS metabolic pathway to suppress tumor cell growth. Sci Rep, 8, 1-13.

Liu H X, Zhang L, Chen YC, et al (2017). Monoterpenes and sesquiterpenes from the marine sediment-derived fungus Eutypella scoparia FS46. J Asian Nat Prod Res, 19,145-51.

Martínez-Martínez E, Martín-Ruiz A, Martín P, et al (2016). CB2 cannabinoid receptor activation promotes colon cancer progression via AKT/GSK3 $\beta$ signaling pathway. Oncotarget, 7, 68781-91.

Meiyanto E, Lestari B, Sugiyanto RN, et al (2019). Caesalpinia sappan L. heartwood ethanolic extract exerts genotoxic inhibitory and cytotoxic effects. Orient Pharm Exp Med, 19, 27-36.

Park MY, Kwon HJ, Sung MK (2011). Dietary aloin, aloesin, or aloe-gel exerts anti-inflammatory activity in a rat colitis model. Life Sci, 88, 486-492.

Pojarová M, Kaufmann D, Gastpar R, et al (2007). [(2-Phenylindol-3-yl) methylene]propanedinitriles inhibit the growth of breast cancer cells by cell cycle arrest in $\mathrm{G} 2 / \mathrm{M}$ phase and apoptosis. Bioorg Med Chem, 15, 7368-79.

Prayong P, Barusrux S, Weerapreeyakul N (2008). Cytotoxic activity screening of some indigenous Thai plants. Fitoterapia, 79, 598-601.

Ramachandhiran D, Sankaranarayanan C, Murali R, Babukumar S, Vinothkumar V (2019). $\beta$-caryophyllene promotes oxidative stress and apoptosis in $\mathrm{KB}$ cells through activation of mitochondrial-mediated pathway-An in-vitro and insilico study. Arch Physiol Biochem, 0, 1-15.

Raup-Konsavage WM, Johnson M, Legare CA, et al (2018). Synthetic cannabinoid activity against colorectal cancer cells. Cannabis Cannabinoid Res, 3, 272-81.

Salim M, Kabeer TKA, Nair A, et al (2016). Chemical profile, anti-proliferative and antioxidant activities of rhizome oil of Zingiber anamalayanum from Western Ghats in India. Nat Prod Res, 30, 1965-8.

Seckl MJ, Rozengurt E (1996). Effect of tyrphostin combined with a substance P related antagonist on small cell lung cancer cell growth in vitro. Eur J Cancer, 32, 342-5.

Shah M, Qureshi MFH, Mohammad D, et al (2020). CDKs family -a glimpse into the past and present: from cell cycle control to current biological functions. Asian Pac J Cancer Biol, 5, 1-9.

Wu H, Lu XX, Wang JR, et al (2019). TRAF6 inhibits colorectal 
cancer metastasis through regulating selective autophagic CTNNB1/ $\beta$-catenin degradation and is targeted for GSK3B/ GSK $3 \beta$-mediated phosphorylation and degradation. Autophagy, 15, 1506-22.

Wulandari F, Ikawati M, Meiyanto E, Kirihata M, Hermawan A (2020). Bioinformatic analysis of CCA-1.1, a novel curcumin analog, uncovers furthermost noticeable target genes in colon cancer. Gene Rep, 21, 100917.

Xiang W, Shi R, Kang X, et al (2018). Monoacylglycerol lipase regulates cannabinoid receptor 2-dependent macrophage activation and cancer progression. Nat Commun, 9, 2574.

Zulfin UM, Rahman A, Hanifa M, et al (2021). Reactive oxygen species and senescence modulatory effects of rice bran extract on 4T1 and NIH-3T3 cells co-treatment with doxorubicin. Asian Pac J Trop Biomed, 11, 174-82.

\section{c) (i) (8)}

This work is licensed under a Creative Commons AttributionNon Commercial 4.0 International License. 